\title{
New Edge Detection Method Using Elisabeth Method: Case Study Javanese Batiks
}

\author{
Elisabeth Denis Setiani, Suyoto \\ Master of Informatics Engineering Department, University of Atma Jaya Yogyakarta \\ Jl. Babarsari No. 43, Yogyakarta 55281, Indonesia \\ Email: lizbethdd246@yahoo.com
}

\begin{abstract}
This article will introduce a new edge detection method called Elisabeth method to analyze image. The case study here is Javanese Batik's motif. Edges are basic low level primitives for image processing. It helps to identify pictures. Methods used are the combination between Sobel and Prewitt. This method is completely new to analyze Javanese Batik's motif. Every batik motif has unique pattern. The purpose of this research is to improving edge detection method that already known now. The result is a new method in edge detection problems. Batik is one of the Indonesian Heritage that avowed as a Heritage World Cultures. With this research it hoped can help our country to classify and identify Batik's motif items in Indonesia.
\end{abstract}

Keywords: Prewitt, Sobel, Elisabeth, Javanese Batik, Parang, Kawung

\begin{abstract}
Abstrak. Metode Baru Deteksi Tepi Menggunakan Metode Elisabeth: Studi Kasus Batik Jawa. Artikel ini akan memperkenalkan sebuah metode baru deteksi tepi yang disebut dengan metode Elisabeth untuk menganalisis citra. Studi kasus yang digunakan disini adalah motif Batik Jawa. Tepi adalah primitif level dasar untuk pemrosesan citra. Ini membantu mengidentifikasi gambar. Metode yang digunakan adalah kombinasi antara Sobel dan Prewitt. Metode ini benar-benar baru untuk menganalisis motif Batik Jawa. Setiap motif batik memiliki pola yang unik. Tujuan dari penelitian ini adalah untuk meningkatkan metode deteksi tepi yang sudah dikenal sekarang. Hasilnya adalah metode baru dalam masalah deteksi tepi. Batik adalah salah satu Warisan Indonesia yang diakui sebagai Warisan Budaya Dunia. Dengan penelitian ini diharapkan dapat membantu negara kita untuk mengklasifikasikan dan mengidentifikasi motif Batik di Indonesia.
\end{abstract}

Kata Kunci: Prewitt, Sobel, Elisabeth, Batik Jawa, Parang, Kawung

\section{Introduction}

Image processing is one of great technology. Image processing aimed at improving the image quality to be easily interpreted by humans or machines (in this case a computer). Image processing have been using computer systems applied to a number of areas, such as in medicine, biology, law, and security.Image processing techniques to transform the image into another image. Thus, the input is the image and the output image as well, but the output image should have a better quality than the input image. Image processing operations can be classified in several types of image quality improvement, image restoration, image segmentation, image analysis and image reconstruction.(Agushinta, 2007) For image processing, the image must already be in the form of digital image. A digital image can be considered as a matrix whose 
row and column indices identify a point in the image and the corresponding matrix element value identifies the gray level at that point. (Anam, 2009)

One of the big issues in image processing is edge detection. Determine the position of the edge of an imageis easy, if the condition is clear and the image sharp (sharp), but the accuracy of the existence edge becomes difficult to determine if the there image disturbances, such as the noise. In fact image-acquisition result, not alwaysis clean of noise. (Febriani, 2008) The benefits if we can implement the edge detection are many in subject. The edge detection help to identify and clasify object. In this paper the case study is Javanese Batik because Javanese Batik is very complex and has many different motif and really to be classified.

\section{Literature Review}

\subsection{Edge Detection}

In Image Processing, an edge is the boundary between anobject and its background. (Martin) Edges are those places in an image that correspond to object boundaries and an edge is a pixel where image brightness changes abruptly. Edge detection is one of the most commonly used operations in image analysis. An edge is defined by adiscontinuity in gray level values. (Sharifi)Edges define the boundaries between regions in an image, which helps with segmentation and object recognition. They can show where shadows fall in an image or any other distinctchange in the intensity of an image. (Nadernejad, 2008) It describes the spatial differences accross an image. These differences form boundaries that allow the human visual system to distinguish between homogeneus colour regions in an image. Similarly, contentbased image retrival system use low-level edges in higher level feature extracting techniques such as contour extraction and texture analysis to differentiate between regions with an image.

Edge detection is a process to an image that produce edges from object that we process.Edge detection is a fundamental tool used in most image processing applications to obtain information from the frames as a precursor step to feature extraction and object segmentation.Edge detection is a very important feature-extraction method that has been widely used in many computer vision and image processing applications. The basic idea of most available edge detectors is to locate some local object-boundary information in an image by thresholding and skeletonizing the pixel-intensity variation map. (Wang, 2006)

The purposes of edge detection are: (1) To mark the section to detail image. (2) To improve the detail of the blurred image which occurs because error or the effects of the image acquisition process. (3) A point ( $x, y$ ) is said to be the edge (edge) of an image when the point has a height difference with the neighboring.

\subsubsection{Prewitt Method}

Prewitt Method is one of gradient edge detector which contains classical operators and uses firstdirectional derivative operation. (Sharifi) Prewitt Method is a method of edge detection in image processing which calculates the maximum response of a set of convolution kernels to find the local edge orientation for each pixel. This method is derived from method robert that is developing methods to use a filter that FSH was given a zero buffer.This method takes the principle of the Laplacian function is known as a function to generate FSH.

The Prewitt edge detector consider the arrangement of pixels about the pixel (i,j). The matrix with pixel $(\mathrm{i}, \mathrm{j})$ shown as $\left[\begin{array}{ccc}a 0 & a 1 & a 2 \\ a 7 & {[i, j]} & a 3 \\ a 6 & a 5 & a 4\end{array}\right]$. The partial derivatives can be computed by the formula 1 to compute the horizontal side and using formula 2 to compute the vertical side. The constant $c$ implies the emphasis given to pixels closer to center of the mask. Setting $c=1$ and then we get the Prewitt Operator. (Agushinta, 2007) (Herdiyeni) (Trucco). The Prewitt matrix 
shown in formula 3 . We can find the edge magnitude using formula 4 and can find the edge direction using formula 5 .

\section{Formula 1. Horizontal Side in Prewitt}

$P x=(a 2+c a 3+a 4)-(a 0+c a 7+a 6)$

\section{Formula 2. Vertical Side in Prewitt}

$\mathrm{Py}=(\mathrm{a} 6+\mathrm{ca} 5+\mathrm{a} 4)-(\mathrm{a} 0+\mathrm{ca} 1+\mathrm{a} 2)$

Formula 3. Prewitt Matrix

$P x=\left[\begin{array}{lll}-1 & 0 & 1 \\ -1 & 0 & 1 \\ -1 & 0 & 1\end{array}\right] \quad \mathrm{P} y=\left[\begin{array}{ccc}-1 & -1 & -1 \\ 0 & 0 & 0 \\ 1 & 1 & 1\end{array}\right]$

Formula 4. Edge Magnitude in Prewitt

Edge magnitude is $\sqrt{P x+P y}$

Formula 5. Edge Direction in Prewitt

Edge direction $=\tan ^{-1}\left[\frac{p_{y}}{p_{x}}\right]$

The Prewitt operator measures two components. The vertical edge component is calculated with kernel Px and the horizontal edge component is calculated with kernel Py. $|\mathrm{Px}|+$ $|\mathrm{Py}|$ give an indication of the intensity of the gradient in the current pixel.

\subsubsection{Sobell Method}

Sobel method is one of edge detection method beside Prewitt method. Sobel is one of gradient edge detector which contains classical operators and uses firstdirectional derivative operation. (Sharifi) The Sobel operator is used in image processing, particularly within edge detection algorithms. Technically, it is a discrete differentiation operator, computing an approximation of the gradient of the image intensity function. At each point in the image, the result of the Sobel operator is either the corresponding gradient vector or the norm of this vector.

The Sobel operator is based on convolving the image with a small, separable, and integer valued filter in horizontal and vertical direction and is therefore relatively inexpensive in terms of computations. On the other hand, the gradient approximation which it produces is relatively crude; in particular for high frequency variations in the image. The Sobel edge detection operator is based on first derivative based operation. The algorithms of first derivative or first difference based operator are the simplest one that is why it is selected for implementation on hardware device. (Abbasi)

The advantages of this Sobel method is the ability to reduce noise prior to edge detection calculations.The Sobel edge detector uses two masks, one vertical and one horizontal. These masks are generally used $3 \times 3$ matrixes. The common Sobel edge detector which have $3 \times 3$ horizontal and vertical masks is used in the edge function (Aybar) The Sobel operator performs a 2-D spatial gradient. The operator consists of several $3 \times 3$ convolution masks (kernels). Other masks we obtain a simply rotation by $45^{\circ}$. (Vener) Sobel Operator is magnitude 
from gradient. The matrix with pixel $(i, j)$ shown as: $\left[\begin{array}{ccc}a 0 & a 1 & a 2 \\ a 7 & {[i, j]} & a 3 \\ a 6 & a 5 & a 4\end{array}\right]$. The partial derivatives can be computed by the formula 6 to computed the horizontal side and using formula 7 to compute the vertical side. The constant $\mathrm{c}$ implies the emphasis given to pixels closer to center of the mask. Setting $c=2$ and then we get the Sobel Operator. (Agushinta, 2007) (Herdiyeni) (Trucco) The Sobell matrix shown in formula 8 . We can find the edge magnitude using formula 9 and can find the edge direction using formula 10.

\section{Formula 6. Horizontal Side in Sobell}

$\mathrm{Sx}=(\mathrm{a} 2+\mathrm{ca} 3+\mathrm{a} 4)-(\mathrm{a} 0+\mathrm{ca} 7+\mathrm{a} 6)$

\section{Formula 7. Vertical Side in Sobell}

$\mathrm{Sy}=(\mathrm{a} 0+\mathrm{ca} 1+\mathrm{a} 2)-(\mathrm{a} 6+\mathrm{ca} 5+\mathrm{a} 4)$

Formula 8. Sobell Matrix

$S x=\left[\begin{array}{lll}-1 & 0 & 1 \\ -2 & 0 & 2 \\ -1 & 0 & 1\end{array}\right] \quad S y=\left[\begin{array}{ccc}-1 & -2 & -1 \\ 0 & 0 & 0 \\ 1 & 2 & 1\end{array}\right]$

Formula 9. Edge Magnitude in Sobell

Edge magnitude is $\sqrt{S x+5 y}$ or $\mathrm{S}=|\mathrm{Sx}|+|\mathrm{Sy}|$

Formula 10. Edge Direction in Sobell

Edge direction $=\tan ^{-1}\left[\frac{S y}{S x}\right]$

Sobel operator detects thicker edges (Tandon) and both Prewitt and Sobel have simplicity, good in detection of edges and their orientations. But the disadvantage of these metod are sensitivity to noise and inaccurate. (Sharifi) If there are noises in the result then the edge will not clear and it is hard to find accurately about the edges.

\subsection{Javanese Batik}

In this paper we propose a new edge detection method for image. The case study in this experiment is Javanese Batik. Organization of Education, Science and Culture of the United Nations or UNESCO set batik as a world heritage originating from Indonesia. Batik assessed as a cultural icon that is unique and in-depth philosophy and includes the human life cycle that is set as the Cultural heritage non object of human body. (Kompas, 2009)

Batik Craft have been developed from generation to generation as genuine clothing products of Indonesian Heritage. From the era of pre-history, Hinduism, Islam, Colonial Time, the period of independent struggle, untill the present time of development era, batiks have continously developed in its motive, design and technology. Indonesian batiks have its own characteristic such as: the making process is using blocking dyeing technique, the blocking material is wax with particular ingredients, the motive has specific characteristic, arranged from ornaments that have beautiful nuance as well as symbolic meaning showing Indonesian personality. (NAFED, 2005)

Indonesian Batik divided into many different batik based on their origin. There are Javanese Batik, Kalimantan Batik, Jambi Batik, etc. One of the purposes of this research is to 
help our country to classify and identify Batik's motif items in Indonesia. Javanese Batik has unique and specific pattern. Javanese batik is very unique and divided into many clasiffication based on its motive. Here are the examples of Javanese batik motive.

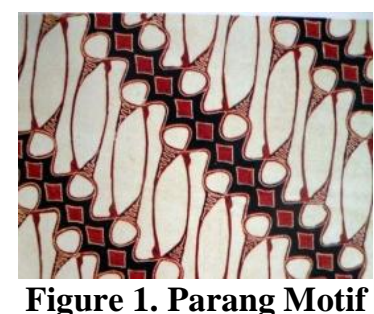

In Figure 1 we present Parang Motif. This motif gently curved design is run diagonally in a powerful rhythm; the space between parallel runnings is filled with small ornaments (isenisen). (Moertini) Parang Motif was once used exclusively by the royal courts of Central Java or "priyayi Kraton". The philosophy of this motif is people who wear shows authority. (PIKM) It has several suggested meanings such as 'rugged rock', 'knife pattern' or 'broken blade'. The Parang design consists of slanting rows of thick knife-like segments running in parallel diagonal bands. Parang usually alternated with narrower bands in a darker contrasting color. These darker bands contain another design element, a line of lozenge-shaped motifs call mlinjon. There are many variations of this basic striped pattern with its elegant sweeping lines, with over forty parang designs recorded. The most famous is the 'Parang Rusak' which in its most classical form consisting of rows of softly folded parang. This motif also appears in media other than batik, including woodcarving and as ornamentation on gamelan musical instruments.

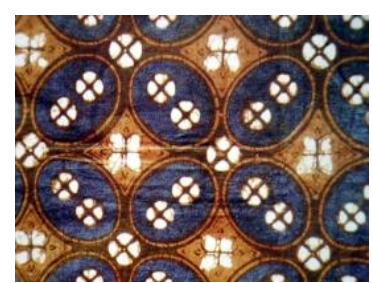

Figure 2. Kawung motif

In figure 2 we present Kawung Motif. This motif is repetitive shapes of circle, ellip, square, square withsmooth corner, rosette, star, cross sections of fruit. (Moertini) Kawung Motif is another very old design consisting of intersecting circles, known in Java since at least the thirteenth century. This design has appeared carved into the walls of many temples throughout Java such as Prambanan near Jogjakarta and Kediri in East Java. For many years, this pattern was reserved for the royal court of the Sultan of Jogjakarta. The circles are sometimes embellished inside with two or more small crosses or other ornaments such as intersecting lines or dots. It has been suggested that the ovals might represent flora such as the fruit of the kapok (silk cotton) tree or the aren (sugar palm).

\section{Research Methodology}

\subsection{Elisabeth Method}

Elisabeth method is a new method in Edge detection which combining between Prewitt and Sobel method. The result is a new method that provides good result and less noise. The concept of Elisabeth Matriks is quite simple. We just take $\mathrm{X}$ component from Prewitt matriks and then combining with Y component from Sobel method. The purpose of this method is combining and complementary the advantages and disdvantages of both method that are Prewitt and Sobel method. The explaination about Elisabeth method is shown below. The formula 11 is 
from $\mathrm{X}$ component of Prewitt matrix that used to process the picture horizontally and the formula 12 is from Y component of Sobel matrix that used to process the picture vertically.

Formula 11. Horizontal Side in Elisabeth

$\mathrm{Ex}=\mathrm{Px}=\left[\begin{array}{lll}-1 & 0 & 1 \\ -1 & 0 & 1 \\ -1 & 0 & 1\end{array}\right]$

Formula 12. Vertical Side in Elisabeth

Ey $=S y=\left[\begin{array}{ccc}-1 & -2 & -1 \\ 0 & 0 & 0 \\ 1 & 2 & 1\end{array}\right]$

Formula 13. Elisabeth Matrix

$\left[\begin{array}{lll}-1 & 0 & 1 \\ -1 & 0 & 1 \\ -1 & 0 & 1\end{array}\right] \quad\left[\begin{array}{ccc}-1 & -2 & -1 \\ 0 & 0 & 0 \\ 1 & 2 & 1\end{array}\right]$

This method use Prewitt matrix as the $\mathrm{X}$ matrix than Sobel matrix. Prewitt method used is the first matrix because it gives a clear view of picture. Prewitt as the $\mathrm{X}$ matrix gives less noises in the result. The edge is clearer than sobel method and it also reduce noise in edge detection result. If the result have less noise then the edge result will be clear.

Algoritm of this method: (1) Give the $X$ matrix value from Prewitt $X$ matrix shown in formula 14. (2) Give the Y matrix value from Sobel Y matrix shown in formula 15. (3) Take $3 \times 3$ Matrix from the picture. The example is shown in formula 16. (4) The first process is horizontal filter using Ex and Pm. The formula is shown in formula 17 and formula 18. The result is pixel 1 until 9 in the $3 \times 3$ matrix of new picture. Each pixel represents each component of the matrix. This formula is just ordinary multiplication matrix but after being multiply it will be square root in each pixel. (5) Repeat the step 3 and 4until the picture is processed by horizontal filter. (6) Repeat step 3 - 5 using Ey and Pm until the picture is processed by vertical filter. This process actually quite simple to detect edges in an image, we used a detector program that using convolution mask. In each case, we apply a horizontal version of the filter to one bitmap, a vertical version to another, and used the formula 19 to merge them.

Edge detection filters work essentially by looking for contrast in an image. This can be done by many different ways. The convolution filters do it by applying a negative weight on one edge, and a positive on the other. This has the net effect of trending towards zero if the values are the same, and trending upwards as contrast exists.

\section{Formula 14. Prewitt X Matrix}

$\mathrm{Ex}=\left[\begin{array}{lll}E x 1 & E x 2 & E x 3 \\ E x 4 & E x 5 & E x 6 \\ E x 7 & E x 8 & E x 8\end{array}\right]=\left[\begin{array}{lll}-1 & 0 & 1 \\ -1 & 0 & 1 \\ -1 & 0 & 1\end{array}\right]$

Formula 15. Sobel Y Matrix

Ey $=\left[\begin{array}{lll}\text { Ey1 } & \text { Ey2 } & \text { Ey3 } \\ \text { Ey4 } & \text { Ey5 } & \text { Ey6 } \\ \text { Ey7 } & \text { Ey8 } & \text { Ey9 }\end{array}\right]=\left[\begin{array}{ccc}-1 & -2 & -1 \\ 0 & 0 & 0 \\ 1 & 2 & 1\end{array}\right]$ 
Formula 16. 3x3 Matrix

$\mathrm{Pm}=\left[\begin{array}{lll}A & B & C \\ D & E & G \\ G & H & I\end{array}\right]$

Formula 17. Horizontal Filter using Ex

Formula pixel $1=\operatorname{sqrt}(\operatorname{Ex} 1 * \mathrm{~A}+\mathrm{Ex} 3 * \mathrm{~B}+\mathrm{Ex} 4 * \mathrm{C})$

Formula 18. Horizontal Filter using Pm

Formula pixel $2=\operatorname{sqrt}(\mathrm{Ex} 2 * \mathrm{~A}+\mathrm{Ex} 5 * \mathrm{~B}+\mathrm{Ex} 8 * \mathrm{C})$

Formula 19. Merging Formula

Formula pixel $=\operatorname{sqrt}(\operatorname{pixel} 1 * \operatorname{pixel} 1+\operatorname{pixel} 2 * \operatorname{pixel} 2)$

\section{Experimental Result}

\subsection{Parang Motif}

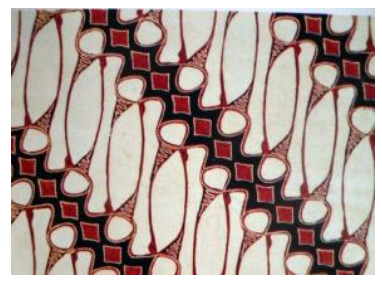

Figure 3. Original image of Parang Motif

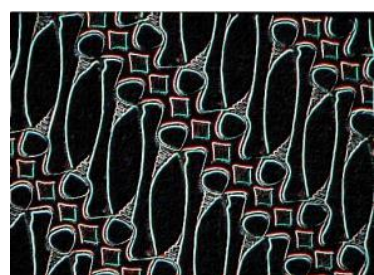

Figure 4. Parang Motif Result from Prewitt Method

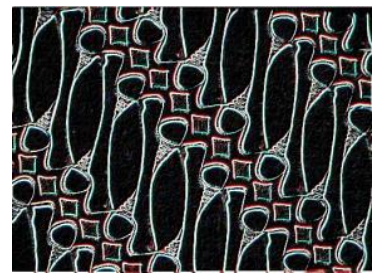

Figure 5. Parang Motif Result from Sobel Method

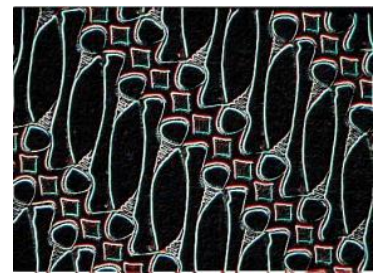

Figure 6. Parang Motif Result from Elisabeth Method 
From the results above we can have conclusion that Prewitt, Sobel and Elisabeth method still have noise in the result. Prewitt have weakness in detecting curve line and Sobel have weakness in detecting area that have have similarity of color but quite good in detecting curve line. Elisabeth method try to fix these weaknesses and the result is in curve line the result is good. The edge look sharper and the area that Sobel can not do is more clear and sharp than before. But this method have weakness that is the blur area (areas that have similarity of colorwith neighborhood pixel) still not very sharp like we want but better than the other method.

\subsection{Kawung Motif}

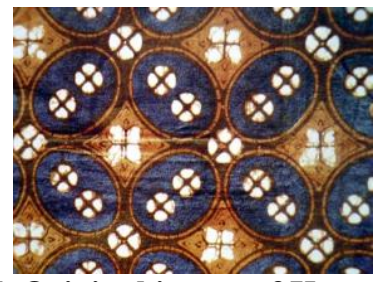

Figure 7. Original image of Kawung Motif

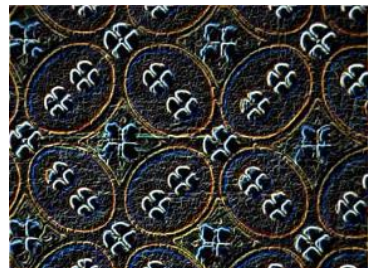

Figure 8. Kawung Motif from Prewitt Method

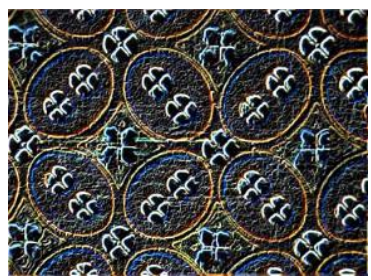

Figure 9. Kawung Motif from Sobel Method

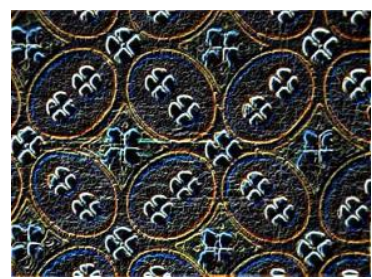

Figure 10. Kawung Motif from Elisabeth Method

From the results above we have a conclusion that Prewitt, Sobel and Elisabeth method still have noise in the result like we discuss above before. Elisabeth method is combination of both methods that give a result with clearer and sharper image and the curve and straight line is better than before. But it still can not make the blur area is very sharp like we want. It just makes it better than before. It covers the weakness of Prewitt and Sobel method and give the new result that better for edge detection.

\subsection{Elisabeth Method Implementation}

For implementation of this method, it has been built a simple program to show how this method works. And the result of this program has shown as figure 11. 


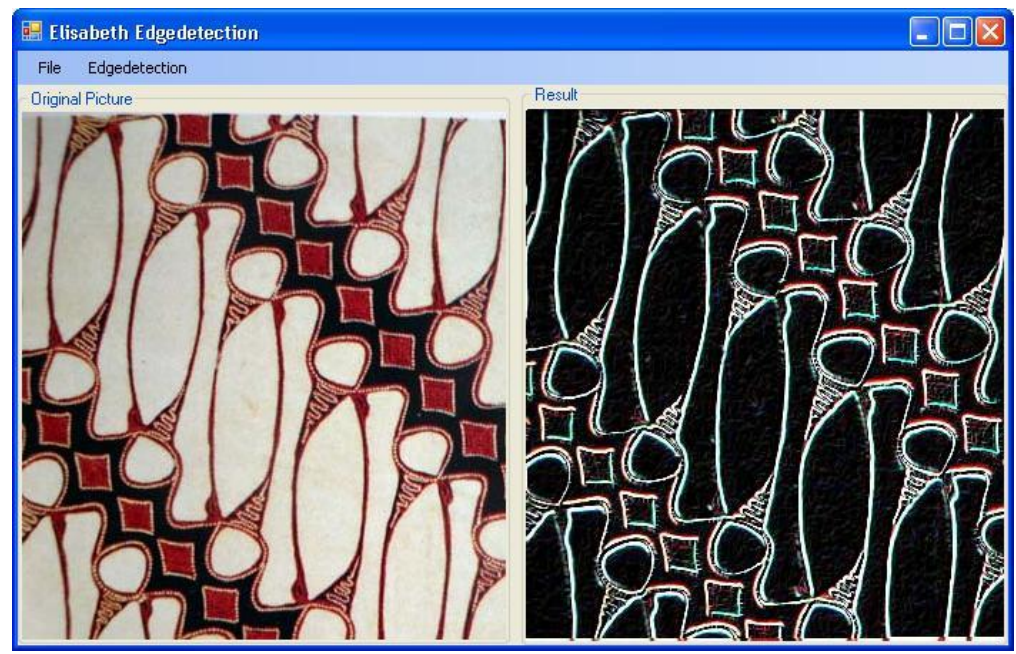

Figure 11. Implementation Program of Elisabeth method

\section{Conclusion}

Elisabeth method is combining between Prewit and modification of Sobel Method. This new method is complementary between Prewitt and Sobel advantages and disadvantages. Prewitt is given in the matrix X because Prewitt have some benefits that are: (1) Prewitt has good method in handling straight line. (2) Using Prewitt method giving the result a noise reduction. The matrix $\mathrm{X}$ is is the first matix and this matrix is very important to the result. Matrix $\mathrm{X}$ is the main matrix. If we use Prewitt as the first matrix than the result must be less noise and having good edge detection in handling straight vertical line. The matrix $Y$ is modification of Sobel matrix. Sobel matrix is quite simple and easy to modificate. The Sobel method give result with more noise but quite good in detecting curve line.

Elisabeth method is combining both of methods. The results of Elisabeth Method are: (1) Good in detecting straight vertical and horisontal line. (2) Reduce noise so the result is clearer. (3) For curve line the result is better and clear. (4) When the color have similarity of color with neighborhood pixel the edge detection result is not really clear. (5) This method is complementary between 2 method so its combining the advantages and disadvantages from Prewitt and Sobel Method.

\section{References}

Abbasi, T.A., Abbasi, M.U. A Proposed FPGA Based Architecture for Sobel Edge Detection Operator. New Delhi: J. of Active and Passive Electronic Devices, II: 271-277.

Agushinta, D., Diyanti, A. 2007. Perbandingan Kinerja Metode Deteksi Tepi Pada Citra Wajah, UG Jurnal, I (2).

Anam, S.I., Kashem, M.A., Rahman, M.A. 2009. Real Time Face Recognition Using Step Error Tolerance BPN, International Journal of Engineering and Technology, I (1): 1793-8236.

Aybar, E., Sobel Edge Detection Method for Matlab, Turkey: Porsuk Vocational School, Anadolu University.

Febriani, L. 2008. Analisis Penelusuran Tepi Citra menggunakan Detektor Tepi Sobel dan Canny. Proceeding Seminar Ilmiah Nasional Komputer dan Sistem Intelijen, Jakarta, (KOMMIT 2008).

Herdiyeni, Y. Deteksi Tepi (Edge Detection). Bogor: Departemen Ilmu Komputer FMIPA IPB. Kompas. 29 September, 2009. Budaya Indonesia: Batik Jadi Warisan Budaya Dunia. 
Martin, A., Tosunoglu, S. Image Processing Techniques For Machine Vision. Florida: Florida International UniversityDepartment of Mechanical Engineering.

Moertini, V.S. Towards Classifying Classical Batik Images. Bandung: Dept. Teknik Informatika ITB (Doctorate Student), Labtek.

Nadernejad, E. 2008. Edge Detection Techniques: Evaluations and Comparisons, Applied Mathematical Sciences, II (31): 1507 - 1520.

NAFED. 2005. Batiks Exotic Clothing of Indonesian Heritage, Indonesia Export News, XV.

PIKM. Katalog Batik Khas Yogyakarta. Yogyakarta: Kantor Wilayah Departemen Perindustrian Provinsi Daerah Istimewa Yoyakarta, P.28-29.

Sharifi, M., Fathy, M., Mahmoudi, M.T. A Classified and Comparative Study of Edge Detection Algorithms, Tehran: Department of Computer Engineering Iran University of Science and Technology Narmak.

Tandon, S. Edge Detection (Presentation Style). Arlington: Course \# EE6358 Computer Vision, Department of Electrical Engineering, University of Texas at Arlington.

Tran, H., Latecki, L.J. 2002. Edge Detection, Computer Graphics and Image Processing CIS 581 - Fall 2002.

Trucco, Edge Detection, Chapt 4 and Jain et al., Chapt 5.

Vener, J. Searching for Simple Geometric Shapes in Raster Image. Czech: Department of Computer Graphics and Multimedia Brno University of Technology Czech Republic.

Wang, S., Ge, F., Liu, T. 2006. Evaluating Edge Detection through Boundary Detection. EURASIP Journal on Applied Signal Processing, 2006. 